\title{
Toxicological investigations on Ruby Valley pointvetch
}

\author{
M. COBURN WILLIAMS AND RUSSELL J. MOLYNEUX
}

\section{Abatract}

Ruby Valley pointvetch (Oxytropis riparia Litv.), a native of the central Soviet Union, was indvertently introduced into the United States during the early part of the 20th century. Ruby Valley pointvetch has long been eatablihed in southwestern Montana, is spreading into Wyoming and Idaho, and is being investizated for its potential as a formge plant. The plant was analyzed for alfphatic nitro compounds, soluble oxalates, nitrates, cyanide, and swainsonine. Swainsonine is found in 2 native Oxytropis specles and causes the loco syndrome and congestive heart fallure. The plant was tested for toxicity to 1-week-old chicks.

Ruby Valley millivetch teated negative for aliphatic nitro compounds, soluble oxalates, cyanide, and swainsonine. Nitrates were present at nontoxic levels. Leaves, stems, seeds, and pods were nontoxic when fed to chicks for 5 days at $1 \%$ of body weight as dried plant. Extracts of these plant parts fed in one dose at $10 \%$ of body welght (as dried plant) were likewise nontoxic.

Key Words: introduced plant, legume, chemical analysis, swainsonine, foraze

Ruby Valley pointvetch (Oxytropis riparia Litv.) is native to the central Soviet Union east of the Caspian Sea and south and southeast of the Aral Sea (Komarov 1948). Ruby Valley pointvetch is a perennial, subglabrous plant with nearly prostrate branches 70 to $100 \mathrm{~cm}$ long. The corolla of the bluish-purple flowers is 6 to $7-\mathrm{mm}$ long and the standard is about $4.5 \mathrm{~mm}$ wide. Pods are 10 to $12-\mathrm{mm}$ long, 5-mm wide, and hang on 2-mm stipes. The plant flowers from June to August.

Ruby Valley pointvetch was inadvertently introduced into North America and it is the only introduced species of Oxytropis found in the United States. The plant was earlier known as Ruby Valley milkvetch (Astragalus rubyi Green and Morris)(Green and Morris 1935) and thought to be an indigenous species until the taxonomy was clarified and its Russian origin noted by Barneby (1964). The plant is adapted to river valleys, moist meadows, waterways, and other areas where ample water is available. Ruby Valley pointvetch was well established in the Ruby (hence its common name) and Jefferson River Valleys of southwestern Montana by the early 1930's. The plant is now found along the Green River northwest of Green River, Wyo., and along the Snake River on the Fort Hall Indian Reservation north of Pocatello, Idaho. Ruby Valley pointvetch is prolific and is considered excellent pasture forage in southwestern Montana. No livestock losses have been reported from the plant. The forage is reported similar to alfalfa for protein, $\mathrm{N}$-free extract, crude fiber, ether extract, and ash content, and 50 to $70 \%$ higher in $\mathrm{P}$ content than alfalfa when grown on P-deficient soils (Green and Morris 1935). The effects of temperature, water stress, and scarification on seed germination and establishment have been studied (Delaney et al. 1986, Hicks et al. 1987, Townsend and McGinnies 1972).

Two species of Oxytropis native to the western United States, Lambert crazyweed ( $O$. Lambertii Pursh) and silky crazyweed ( $O$. sericea Nutt. ex T. \& G.), have long been known to cause the loco syndrome in livestock (Ralphs et al. 1986). The toxic compound

\footnotetext{
Authors are plant physiologist, Poisonous Plant Research Laboratory, Agricultural Research Service, USDA. Loran. Utah 84321, in cooperation with the Utah Agricultural Experiment Station, Logan; and research chemist, Western Regional Research Center, Agricultural Research Service, USDA, Albany, California 94710. Utah Agricultural Experiment Station Journal Contribution No. 3525. Manuscript accepted 5 April 1988.
}

responsible for locoism is swainsonine, a potent inhibitor of $\alpha$ mannosidase. Swainsonine was first isolated from the genus Swainsona in Australia (Colegate et al. 1979), then later from Astragalus lentiginosus Dougl. ex Hook. in the United States (Molyneux and James 1982). Swainsonine has been identified in both Lambert and silky crazyweeds (Molyneux et al. 1985). Swainsone has also been isolated from several other species of Astragalus in North America, 6 species of Swainsona in Australia, and from the fungus Rhizoctonia leguminicola (Schneider et al. 1983).

Silky crazyweed has also been shown to cause congestive heart failure in cattle that graze the plant at high elevations (James et al. 1985). This plant also causes abortions and death. Consumption of plants that contain at least 0.02 to $0.03 \%$ swainsonine (dry weight) and above may cause toxicosis in livestock.

Because Ruby Valley pointvetch is spreading in the western United States and is being examined for its potential as a crop plant, its examination for toxic compounds, particularly swainsonine, is important to insure that it will not endanger livestock. The presence of toxic levels of swainsonine would make the plant objectionable and necessitate efforts to control it and prevent its spread.

In this study, Ruby Valley pointvetch was analyzed for several toxic compounds and fed as dried plant and extract to chicks as an assay for poisonous properties.

\section{Materials and Methods}

Ruby Valley pointvetch was collected from a hay meadow 4 miles north and 4 miles west of the headquarters at the Fort Hall Indian Reservation north of Pocatello, Idaho. Collections were made 9 July 1987, when the plant was in bloom, and 12 August 1987, when the plants had both green and black (mature) pods. The plant was separated into leaves, stems, and flowers, green pods with seeds, empty black pods, and seeds. Plants were analyzed for presence of cyanide (Anonymous 1980), nitro compounds (Williams and Norris (1969), and soluble oxalates (Dye 1956). Nitrate analyses were performed at the Utah State University Soil Testing Laboratory.

Analysis for swainsonine was carried out by extraction of the ground plant material $(0.5 \mathrm{~g})$ with methanol. The extract was evaporated to dryness, the residue dissolved in $1 \mathrm{~N} \mathrm{HCl}$, filtered and applied to short $(4 \mathrm{~cm} \times 0.5 \mathrm{~cm})$ Dowex $50 \mathrm{~W}-X 81,20-50 \mathrm{mesh}$ ion-exchange column ( $\mathrm{NH}_{4}$ form). The column was washed with an equal volume of distilled water and the retained basic compounds eluted with $0.5 \%$ aqueous ammonium hydroxide. The eluate was evaporated to dryness, redissolved in distilled water and made up to $10 \mathrm{ml}$ in a volumetric flask.

A $100 \mu 1$ portion of the solution was transferred to a reaction vial and evaporated to dryness at $50^{\circ} \mathrm{C}$ under a stream of argon. The residue was dissolved in dry pyridine $(100 \mu 1)$ and treated with BSTFA [N,0-bis(Trimethylsilyl)trifluoroacetamide] $(100 \mu 1)$ at room temperature for $\mathbf{3 0} \mathrm{min}$ to form the TMS derivative. Gas chromatography was carried out on a $0.32 \mathrm{~mm} \times 30 \mathrm{~m}$ SE-30 capillary column with on-column injection. The column was temperature programmed from $120^{\circ} \mathrm{C}$ to $300^{\circ} \mathrm{C}$ at $5 \mathrm{C} / \mathrm{min}$. An authentic sample of swainsonine, treated under the same condi-

'Mention of a trademark or proprietary product does not constitute a guarantee or
warranty of the product by U.S. Department of Agriculture and does not imply warranty of the product by U.S. Department of Agriculture and does
approval to the exclusion of other products that may also be suitable. 
tions, eluted from the column at $14.37 \mathrm{~min}$. None of the plant samples showed a peak at this elution time.

One-week-old Leghorn cockerels $(50 \mathrm{~g} \pm 3 \mathrm{~g}$ ) were fed ground leaves, stems, seeds, and pods of Ruby Valley pointvetch at $1 \%$ body weight daily for 5 days. Four chicks were used per plant part. The chicks were deprived of food and water each preceding night, then given the material in No. 4 gelatin capsules the next morning of each day. They were then given chick mash and water free choice and observed for toxic signs from the first feeding through $\mathbf{8}$ days. Thirty grams each of leaves, stems, pods, and seeds were ground and extracted with ethanol for $24 \mathrm{hr}$ on a Soxhlet extractor. The extract was evaporated to dryness, redissolved in water, and evaporated to $30 \mathrm{ml}$ so that each $\mathrm{ml}$ was equivalent to $1 \mathrm{~g}$ of plant. Two chicks each were given a dose of extract with a syringe and polyethylene catheter. The dose was equivalent to feeding whole plant material at amounts equivalent to $10 \%$ of body weight. The chicks were then given chick mash and water free choice and observed 3 days for toxic signs. Weights of treated and control chicks were recorded daily during the tests.

\section{Results and Discussion}

No toxic signs were observed in chicks fed leaves, stems, pods, or seeds of Ruby Valley pointvetch for 5 days at amounts equivalent to $1 \%$ of body weight. The aqueous extract administered at $10 \%$ of body weight likewise produced no toxic signs. Treated chicks gained weight during the tests at the same rate as the controls.

The plant tested negative for cyanide, soluble oxalates, and nitro compounds. Nitrates were detected at $0.05 \%$, expressed as $\mathrm{KNO}_{3}$. Sublethal poisoning has been observed in livestock that ingested feed containing 0.5 to $1.5 \%$ nitrate; concentrations above $1.5 \%$ are potentially lethal (Kingsbury (1964). Leaves, stems, flowers, seeds, and pods tested negative for swainsonine.

Ruby Valley pointvetch contained none of the toxic compounds commonly associated with livestock poisoning. Of particular significance was the absence of swainsonine, the toxic compound found in 2 native species of Oxytropis responsible for the loco syndrome and congestive right-heart failure in livestock. The only objectionable characteristic of the plant seems to be in hay fields where its somewhat woody stems may foul cutter bars during mowing; and because it dries more slowly than grass, it often retains enough moisture to cause molding in baled hay (personnal communication, Delbert Farmer, Pesticide Control Officer, Fort Hall Indian Reservation, Fort Hall, Ida.).

Because Ruby Valley pointvetch is apparently nontoxic, and compares favorably with alfalfa in nutritional value, it has promise as a pasture forage plant. However, care should be taken to prevent its introduction and spread where it might infest crops or meadows where grass is harvested for hay.

\section{Literature Cited}

Anonymous. 1980. Official methods of analysis. 11th ed. Assoc. Off. Agr. Chem., Washington, DC.

Barneby, R.C. 1964. Atlas of North America Astragalus. Part II. Memoirs of the New York Botanical Garden, Vol 13. New York Botanical Garden, Bronx, NY.

Colegate, S.M., P.R. Dorling, and C.R. Huxtable. 1979. A spectroscopic investigation of swainsonine: an $\alpha$-mannosidase inhibitor isolated from Swainsona canescens. Aust. J. Chem. 32:2257-2264.

Delaney, R.H., R.H. Abernethy, and D.W. Johmeon. 1986. Temperature and water stress effects on germination of Ruby Valley pointvetch ( $O x y$ tropis riparia Litv.). Crop Sci. 26:161-165.

Dye, W.B. 1956. Chemical studies on Halogeton glomeratus. Weeds 4:55-60.

Green, J.R., and H.E. Morris. 1935. A new legume in Montana. J. Amer. Soc. Agron. 27:546-549.

Hicks, L.S., R.D. Hall, L.E. Wiesner, and H. Armstrong. 1987. Germination and establishment of a new forage legume. Abstracts Western Soc. Crop Sci., June 21-24, Laramie, Wyo. p. 18.

Jamea, L.F., W.J. Hartiey, D. Nieluen, S. Allen, and K.E. Panter. 1985. Locoweed (Oxytropis sericea) poisoning and congestive heart failure in cattle. J. Amer. Vet. Med. Assoc. 189:1549-1556.

Kingabury, J.M. 1964. Poisonous plants of the United States and Canada. Prentice-Hall, Inc., Englewood Cliffs, NJ.

Komarov, V.L. 1948. Flora of the U.S.S.R. Vol, 13. Leguminosae: $O x y$ tropis, Hedysarum. Izdatel'stvo Akademii Nauk SSSR, Moskva-Leningrad.

Molyneux, R.J., and L.F. James. 1982. Loco intoxication: indolizidine alkaloids of spotted locoweed (Astragalus lentiginosus). Science 216:190-191.

Molyneux, R.J., L.F. James, and K.E. Panter. 1985. Chemistry of toxic constituents of locoweed (Astragalus \& Oxytropis) species, p. 266-278. In: A.A. Seawright, M.P. Hegarty, L.F. James, and R.F. Keeler (eds.), Plant Toxicology: Queensland Poisonous Plants Committee, Yeerongpilly, Australia.

Ralphs, M.H., L.F. James, and J.A. Pfister. 1986. Utilization of white locoweed (Oxytropis sericea Nutt.) by range cattle. J. Range Manage. 39:344-347.

Schneider, M.J., F.S. Ungemach, H.P. Broquint, and T.M. Harris. 1983. (1S,2R,8R,8aR)-1,2,8-trihydroxyoctahydroindolizine (swainsonine), an $\alpha$-mannosidase inhibitor from Rhizoctonia leguminicola. Tetrahedron 39:29-32.

Townsend, C.E., and W.J. McGinnies. 1972. Temperature requirements for seed germination of several forage legumes. Agron. J. 64:809-812.

Williams, M.C., and F.A. Norris. 1969. Distribution of miserotoxin in varieties of Astragalus miser Dougl. ex Hook. Weed Sci. 17:236-238.

NOTE: Abraham de Alba and Jerry R. Cox, authors of the article "Planting depth and soil texture effects on emergence and production of three alkali sacaton accessions" (JRM, May 1988, p. 216) are ecologist and former graduate student, Instituto de Ecologia, Apartado 18-845, Deleg. Miguel Hidalgo 11800, Mexico City; present address: CEDEC, Apartado 69, Jalpa, Zac, 99600, Mexico; and range scientist, USDA Agricultural Research Service, 2000 E. Allen Road, Tucson, Arizona 85719. Reprint requests should be sent to J.R. Cox. 